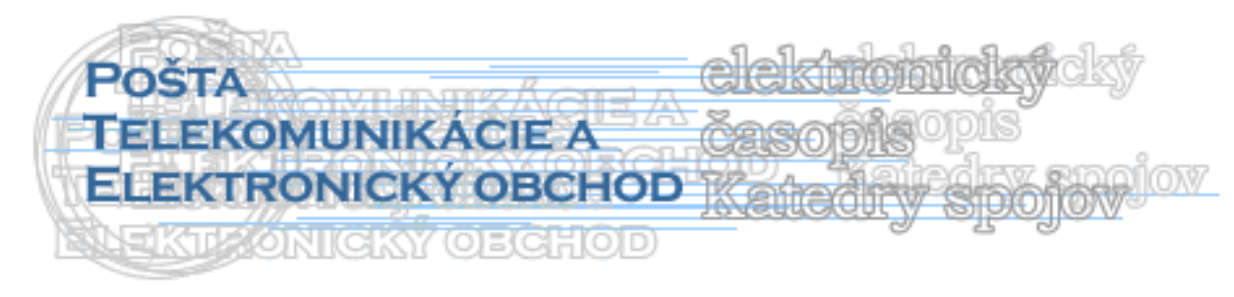

\title{
SIMULAČNÝ MODEL SKLADOVÉHO HOSPODÁRSTVA
}

\author{
Lukáš Achimský*, Veronika Achimská*
}

\begin{abstract}
Abstrakt
Článok poukazuje na možnosti využitia metódy simulácie pri riešení skladového hospodárstva, čo je jednou zhlavných úloh podnikov realizujúcich svoje podnikanie v prostredí internetového obchodu s tovarmi. V článku je tiež navrhnutý jednoduchý algoritmus na výstavbu simulačného modelu, ktorý môže napomôct' zodpovedat' na základné otázky týkajúce sa riadenia skladového hospodárstva.
\end{abstract}

\section{Úvod}

V posledných rokoch charakterizovaných silnou internetizáciou na Slovensku vznikli mnohé podniky, ktoré realizujú predaj tovarov výhradne prostredníctvom internetu. $\mathrm{Na}$ zabezpečenie plynulého chodu predaja $\mathrm{v}$ obchodných systémoch takéhoto typu je potrebné vytvárat' zásoby, ktorých ciel'om je vyrovnávat' okamžitú disproporciu medzi výrobou a spotrebou. Pre tieto podniky je tak jednou z hlavných úloh správne riadenie skladu.

\section{Formulácia problému}

V obchodnej sieti sklady vyrovnávajú rozdiel medzi prísunom tovaru z výroby a dopytom po jednotlivých druhoch tovaru. Základnou potrebou tvorby a udržovania zásob je najmä:

- odlúčenost' výroby od spotreby, čo si vyžaduje zabezpečit' prepravu tovarov do skladov obchodov v určitých dávkach,

- náhodné kolísavé zmeny v spotrebe tovarov,

- t’ažko garantovatel'ný prísun tovarov do skladov pod vplyvom rôznych okolností.

Z uvedeného je zrejmé, vzhl'adom na náhodný charakter niektorých prvkov skladového hospodárstva, že je potrebné riadit' popísaný systém zásobovacieho procesu. Taktiež prípadný model zásobovacieho procesu musí vychádzat' z reálneho dopytu,

\footnotetext{
Ing. Lukáš Achimský, Žilinská univerzita v Žiline, Fakulta PEDAS, Katedra spojov, tel.: $+421 / 0415133145$

e-mail: lukas.achimsky@fpedas.uniza.sk

* Ing. Veronika Achimská, PhD., Žilinská univerzita v Žiline, Fakulta PEDAS, Katedra spojov, tel.: +421/041 5133117

e-mail: veronika.achimska@fpedas.uniza.sk
} 
z požadovaného množstva tovaru, $\mathrm{z}$ intervalov medzi vystavením objednávky a dodaním tovaru na sklad atd'.

Simulačné modely sa bežne používajú pri skúmaní zložitých systémov, kde ide o analýzu, optimalizáciu, prípadne hl'adanie vhodného riešenia. Oblast' zásobovania v rámci skladového hospodárstva môže byt' zložitým systémom. Prostredníctvom modelu zásobovacích procesov možno analyzovat' reálny systém. Vo všeobecnosti úlohou simulačných modelov je napodobňovanie podstatných stránok skúmaných procesov, v našom prípade pre zásobovacie procesy ide o napodobňovanie:

- dopytu po skladovaných tovaroch,

- doplňovania skladu podl'a stanoveného systému objednávacieho režimu, $\mathrm{s}$ napodobnením správania sa v systéme dodávania tovarov - oneskorenie dodávania, odchýlky od deklarovaného oneskorenia, dodávané množstvá po realizovaných objednávkach atd'.

Vo všeobecnosti je dopyt obyčajne realizovaný generovaním náhodných hodnôt príslušných náhodných premenných, avšak v niektorých prípadoch je dopyt realizovaný v pravidelných intervaloch. Spôsob realizácie procesu doplňovania skladu je závislý na spôsobe riadenia skladu a v mnohých prípadoch aj náhodných premenných, ktoré súvisia $\mathrm{s}$ dodacími lehotami, prípadne $\mathrm{s}$ dodávaným množstvom tovaru. Vhodná stratégia riadenia skladu úzko súvisí aj s inými premennými, ktoré môžu významne ovplyvňovat' celé skladové hospodárenie.

Základnou úlohou je vytvorit' simulačný model a následne realizovat' experimenty s modelom s ciel'om nájst' vhodné riadenie skladového hospodárstva, ktoré je súčast'ou obchodu predávajúceho definovaný tovar. Ak uvažujeme o vhodnom riadení skladového hospodárstva z pohl'adu hospodárenia, je základným ukazovatel'om dosiahnutý zisk $(\mathrm{P})$, ktorý v našom zjednodušenom prípade budeme vyhodnocovat' ako funkciu dvoch premenných:

- objednávacieho bodu $\mathrm{R}$ (reálny počet kusov daného tovaru na sklade, pri ktorom riadiaci vystavuje objednávku),

- objednávaného množstva tovaru Q.

Pokial' predpokladáme, že ostatné premenné ovplyvňujúce hospodársky výsledok konkrétneho definovaného produktu sú nemenné, môžeme funkciu zisku zapísat' nasledovane:

$P=f(R, Q)$, ceteris paribus.

Medzi d’alšie dočasne fixné premenné, ktoré môžu budú zobrané do úvahy pri výstavbe modelu zobrazujúceho zjednodušený reálny systém sú:

- predajná cena,

- nákupná cena,

- objednávacie náklady,

- náklady na vedenie skladu,

- strata obchodnej povesti.

Tieto premenné vstupujú do modelu na začiatku jeho tvorby a označujeme ich ako vstupné premenné.

\section{Formulácia matematického modelu}

Z teoretického hl'adiska možno povedat', že sa pokúsime vytvorit' model, ktorý bude diskrétny, stochastický a orientovaný na udalosti. Diskrétny preto, lebo systém ktorý simulujeme možno vnímat' ako diskrétny, t. j. stačí sledovat' dianie len v určitých okamihoch, 
teda $\mathrm{v}$ diskrétnom čase, kedy dochádza $\mathrm{v}$ danom systéme $\mathrm{k}$ zmenám stavu systému. Stochastický preto, že $\mathrm{v}$ modeli vystupujú náhodné premenné s pravdepodobnostnou charakteristikou ako je napríklad dopyt. Udalostný preto, že pre výstavbu časovej osi použijeme udalosti.

Pod pojmom udalost' rozumieme - zmenu stavu systému, ktorá sa vyskytuje $\mathrm{v}$ určitom časovom okamihu. Udalost'ou môže byt' napríklad príchod zákazníka, začiatok či koniec obsluhy a podobne. Usporiadaný zoznam udalostí, v ktorom sú udalosti usporiadané podl'a času ich plánovaného výskytu nazývame kalendár udalostí. Udalosti z kalendára udalostí majú dva povinné atribúty, a to čas udalosti a typ udalosti. Kalendár udalostí spolu s algoritmom výberu udalostí vytvárajú základnú štruktúru simulačného modelu.

Simulačný algoritmus vyberá udalosti z kalendára udalostí na spracovanie, čím sa simuluje tok času v modeli. Výberom časovo najbližšej udalosti je zabezpečené prestavenie aktuálneho simulárneho času do času vybranej plánovanej udalosti. Pri diskrétnej simulácii hovoríme o technike postupu času $\mathrm{k}$ nasledujúcej udalosti. Tento prístup spočíva $\mathrm{v}$ tom, že prírastok času neprebieha rovnakými skokmi, čo znamená, že časové úseky, v ktorých žiadna udalost' nenastáva, preskakuje a zaoberá sa len uskutočnenými udalost'ami. Tento prístup je efektívnejší ako prístup s fixným časovým krokom, pretože spotrebuje menej času na simuláciu.

Pri simulácii modelu skladového hospodárstva nás zaujíma iba zmena stavu modelu v určitých diskrétnych okamihoch. To, čo sa deje medzi týmito okamihmi, môžeme zanedbat'. V našom modeli použijeme nasledujúce nezávislé udalosti:

- udalost' č. 1 - požiadavka na nákup tovaru (DOPYT),

- udalost’ č. 2 - príjem tovaru na sklad (TOVAR),

- udalost’ č. 3 - ukončenie simulácie (UKSIM).

Nezávislá udalost' má obyčajne reprodukčný mechanizmus, t. j. pri jej nastaní plánuje zároveň udalost' rovnakého typu, ale môže vyvolat' aj inú, nasledujúcu závislú udalost'.

\section{Udalost' ‘̌. 1 - DOPYT}

Požiadavkou na nákup tovaru v simulárnom čase T vyvolá príchod d’alšej objednávky rovnakého typu (s tou istou požiadavkou) v čase $\mathrm{T}+\mathrm{K}$. Symbol K vyjadruje dížku intervalu medzi príchodmi objednávok. Možno predpokladat', že dížka tohto intervalu je náhodná premenná s exponenciálnym rozdelením a strednou hodnotou danou intenzitou príchodu objednávok. Preto je vel'kost' intervalu potrebné generovat' náhodne s definovaným rozdelením (Obrázok 6).

Ako je uvedené na Obrázku 6, d’alším krokom je zistenie možnosti uspokojenia požiadavky zákazníka. V prípade, ak dôjde $\mathrm{k}$ neuspokojeniu požiadavky zákazníka, dochádza k zvýšeniu počtu „ušlých“ príležitostí o jednu a naplánujeme návrat do kalendára udalostí. Ak požadovaný tovar je na sklade $\mathrm{k}$ dispozícii, dôjde k uspokojeniu požiadavky zákazníka a zároveň k zvýšeniu počtu predaných jednotiek o jednu, čo vedie k zmene stavu zásob na sklade. Preto je potrebné zozbierat' štatistiky o sklade a znížit' reálnu a účtovnú hodnotu skladu o jednu. Po vykonaní týchto činností nasleduje d’alší krok a tým je porovnávanie účtovej hodnoty množstva jednotiek a hodnoty objednávacieho bodu. Ak účtovná hodnota poklesla na objednávací bod, zvýšime účtovnú hodnotu skladu a vystavíme novú objednávku tovaru, čo vedie k zvýšeniu kusov Q. To je zabezpečené generovaním udalosti „príjem tovaru" $\mathrm{v}$ čase $\mathrm{T}+$ interval dodania a nasleduje návrat $\mathrm{z}$ udalosti. 


\section{Obrázok 1: Postup spracovania udalosti „dopyt“6}

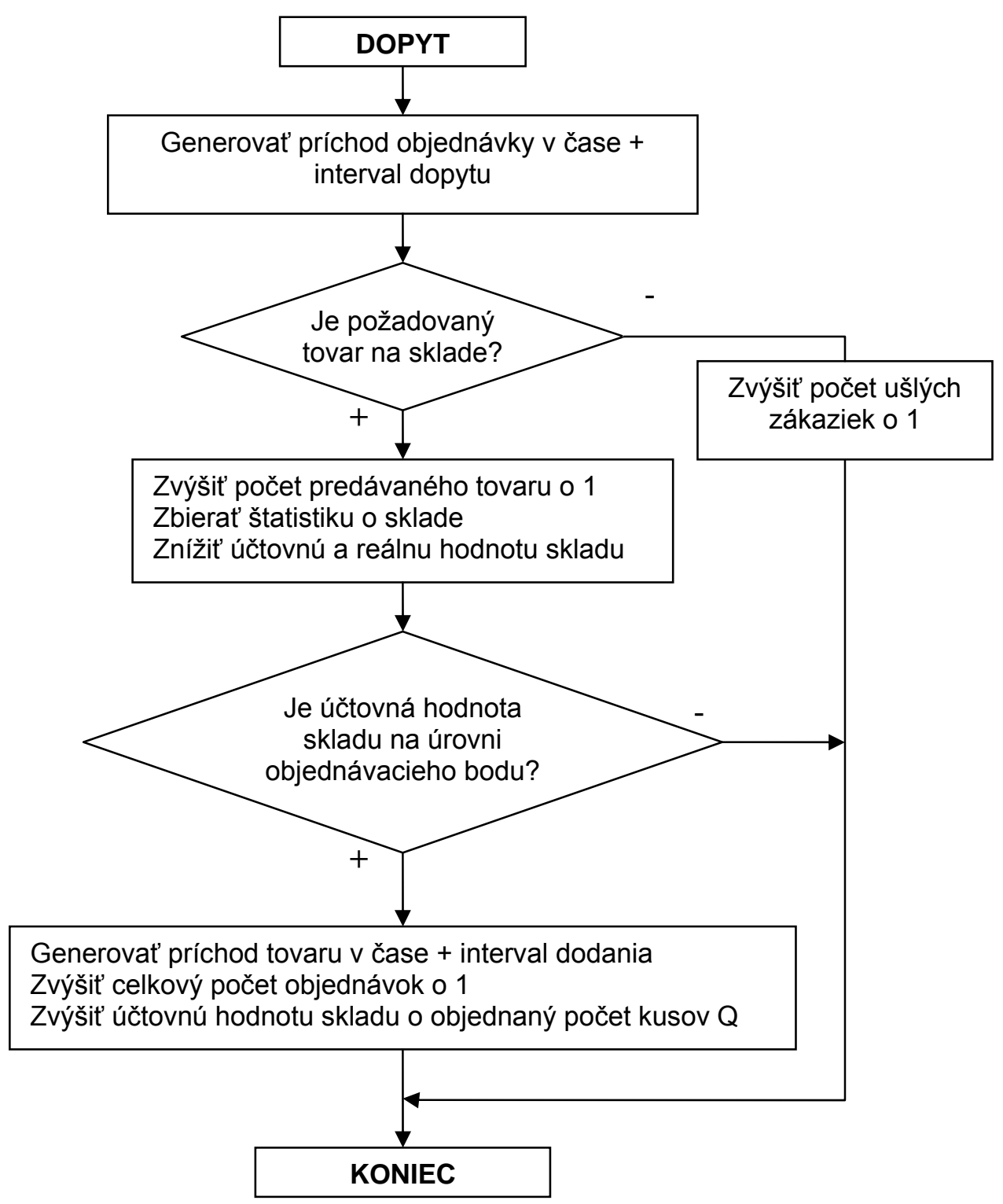

Zdroj: Vlastné spracovanie

\section{Udalost' ‘̌. 2 - TOVAR}

Spôsob spracovania udalosti TOVAR - príjem tovaru (objednaného množstva) na sklad je nasledovný:

V čase, ked' dôjde tovar na sklad, treba vykonat' nasledovné kroky:

- zozbierat' štatistické údaje o stave skladu v dobe prijatia objednaného tovaru (v tomto prípade ide o zozbieranie štatistiky o účtovnej zásobe skladu),

- zozbierat' štatistické údaje o reálnej hodnote skladu.

Po vykonaní týchto činností nasleduje d'alší dôležitý krok, a to zvýšit' počet jednotiek na sklade o prijaté množstvo Q. Postup spracovania udalosti „príjem tovaru“ je na Obrázku 2. 
Obrázok 2: Postup spracovania udalosti „príjem tovaru“6

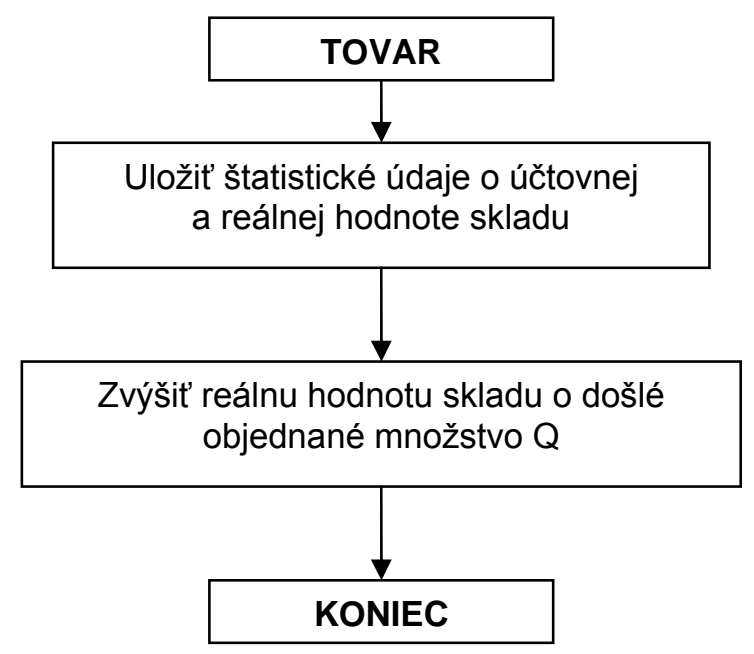

Zdroj: Vlastné spracovanie

\section{Udalost' č. 3 - UKSIM (ukončenie simulácie)}

Ked' dôjde k udalosti určujúcej ukončenie simulácie (UKSIM), aktualizujú sa štatistické údaje o reálnom stave skladu a vypočítavajú sa priemery, ktoré sú potrebné na výpočet zisku. Riadiace premenné sú upravené tak, aby indikovali ukončenie simulácie a spustili výpis záverečných protokolov simulácie. Postup spracovania udalosti „ukončenie simulácie“ je uvedený na Obrázku 8.

\section{Obrázok 3: Postup spracovania udalosti „ukončenie simulácie““}

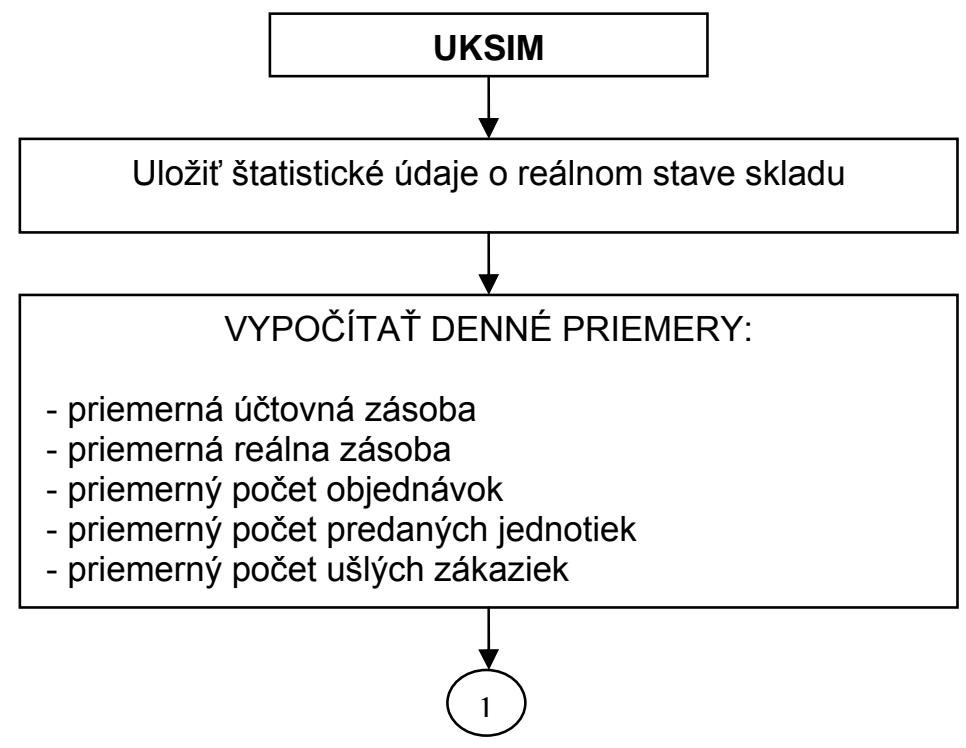




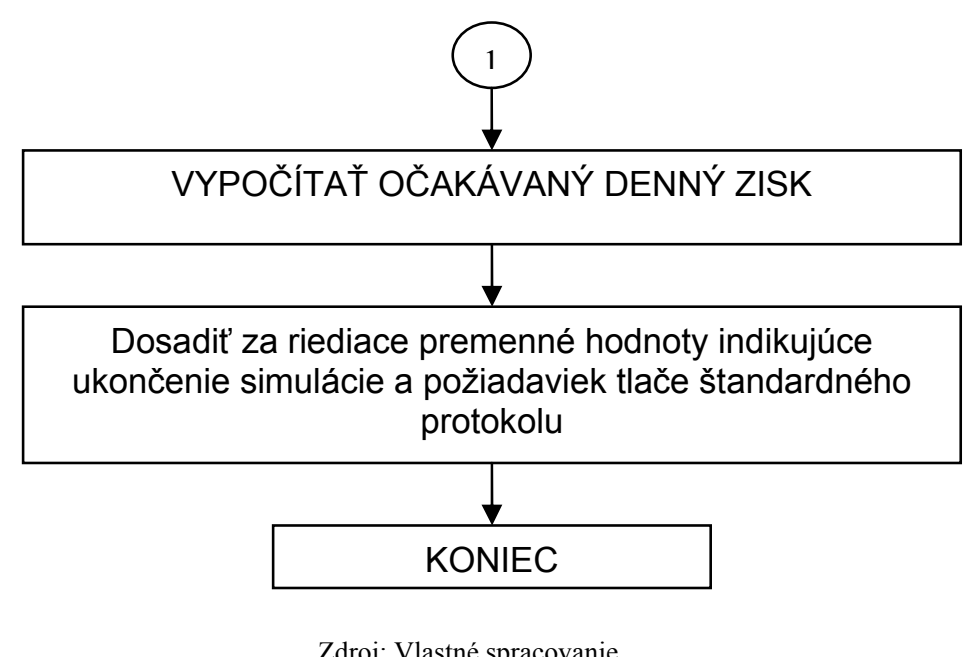

\section{Záver}

Využitie metód simulácie je možné v rôznych sférach ekonomického života. Ako sme naznačili, jednou z nich je aj riadenie skladového hospodárstva. Navrhnutým algoritmom na vytvorenie modelu je možné riešit' len základné otázky v oblasti riadenia. $\mathrm{Na}$ to, aby mal model väčšiu vypovedaciu schopnost', musel by brat' do úvahy d'alšie parametre týkajúce sa konkrétneho skladového hospodárstva. Doplnením týchto parametrov je možné vytvorit' model, ktorý bude simulovat' skutočnost' v čo najväčšej miere.

\section{Literatúra}

[1] KUPKOVIČ, M: 2003. Podnikové hospodárstvo. Bratislava: Svornost', a.s., 2003. 452 s. ISBN 80-88848-71-7

[2] ZALAI, K. a kol.: 1997. Finančno-ekonomická analýza podniku. Bratislava: SPRINT vfra, 1997. 297 s. ISBN 80-88848-18-0

\section{Grantová podpora}

ACHIMSKÁ V. a kol.: Analýza citlivosti počtu kontaktných miest v pomere k nákladom plynúcim z poskytovania UPS. Inštitucionálny výskum - projekt č.1/KS/2012. Žilinská univerzita v Žiline, FPEDAS, 2012. 